\title{
The zero-VAP sophistry and controversies surrounding prevention of ventilator-associated pneumonia
}

\author{
Sebastiano Maria Colombo ${ }^{1,2,3}$, Andrea Catalina Palomeque ${ }^{4,5}$ and Gianluigi Li Bassi ${ }^{1,3,6^{*}}$ (i)
}

(C) 2019 Springer-Verlag GmbH Germany, part of Springer Nature

In critically ill mechanically ventilated patients, ventilator-associated pneumonia (VAP) is the most common iatrogenic pulmonary infection. Diagnosis of VAP is challenging, potentially leading to delayed treatment or overuse of antimicrobials [1]. The impact of VAP on clinical outcomes has been thoroughly investigated [2], but remains a matter of controversy. Indeed, various trials that showed reduction of VAP failed to demonstrate improved clinical outcomes. In addition, the association between VAP and mortality is uncertain, since risk of VAP is time-dependent and patient needs to survive at least until VAP onset, limiting clear extrapolation of mortality risks. Studies attempting to control for these confounding biases have demonstrated VAP attributable mortality slightly higher than $10 \%$ [3]. Irrespective of methodological limitations, substantial body of evidence has been produced in this field and a questionable drive to achieve zero-VAP rates has grown in the past decade. This editorial provides a critical viewpoint on the zeroVAP contradiction, and summarizes controversies surrounding pharmacological and non-pharmacological interventions to reduce VAP rates.

\section{Zero-VAP}

VAP has been increasingly considered as a fully preventable iatrogenic complication and used for benchmark and quality measure, in the context of pay-for-performance programs. This has led to overemphasized reduction in VAP incidence, specifically in North America. Indeed,

*Correspondence: g.libassi@uq.edu.au

${ }^{1}$ Critical Care Research Group, The Prince Charles Hospital, Brisbane, QLD, Australia

Full author information is available at the end of the article in the latest National Healthcare Safety Network report, VAP rates between 0 and 4 per 1000 ventilation-days were described [4], while around the same period, Europeans were reporting an incidence density higher than 8 [5]. International administrators and healthcare policy makers strongly endorsed the "zero-VAP" approach, motivating nation-wide efforts [6], but overlooking its fundamental limitations. First, several promising interventions that reduced VAP risks, did not concurrently curtail secondary outcomes or even use of antibiotics (Table 1), questioning their clinical impact. Second, reliable and accurate diagnostic methods are crucial to corroborate eradication of a preventable disease. To date, a gold-standard to diagnose VAP is still inaccessible and we rely on multiple unspecific assays to score the risk of VAP. The newly proposed definitions of VAP, namely infection-related ventilator condition [8], did not noticeably improve accuracy of VAP diagnosis [7]. This results in easy manipulation of surveillance figures [8], specifically when quality standards or accreditations are needed. More importantly, diagnostic hurdles raise legitimate concerns on the overall evidence in this field of investigation. Indeed, substantial reduction of VAP has been frequently demonstrated by single-centre studies, using before-after designs, heterogeneous diagnostic methods and lacking concealment of interventions [9]. Finally, long-term implementation of strategies to avoid VAP is challenging, requires frequent monitoring of adherence and reinforcements, but even when methodically strategized, adherence rates not greater than $80 \%$ have been achieved [10], implying that sizeable compliance could be an unfeasible goal.

\section{Springer}


Table 1 Evidence-based measures to prevent ventilator-associated pneumonia

\begin{tabular}{|c|c|c|c|}
\hline \multicolumn{4}{|c|}{ Non-pharmacological strategies } \\
\hline Interventions & Preventive mechanisms & Main Effect & Additional Benefits/Limitations \\
\hline $\begin{array}{l}\text { Daily sedation vacation and } \\
\text { spontaneous breathing trials }\end{array}$ & $\begin{array}{l}\text { Reduce length of mechanical ventilation } \\
\text { and associated risks }\end{array}$ & $\begin{array}{l}\text { Approximately 3-day reduction in duration } \\
\text { of mechanical ventilation [13] }\end{array}$ & $\begin{array}{l}\text { Strong additional effect on survival } \\
\text { and ICU-acquired weakness }\end{array}$ \\
\hline Semi-recumbent position $>30^{\circ}$ & $\begin{array}{l}\text { Reduction of gastro-pulmonary } \\
\text { aspiration of pathogens }\end{array}$ & $\begin{array}{l}\text { Reduction in clinically } \\
\text { suspected VAP [15] }\end{array}$ & $\begin{array}{l}\text { Evidence is limited with a high risk } \\
\text { of bias. No concomitant reduction } \\
\text { in other major outcomes }\end{array}$ \\
\hline $\begin{array}{l}\text { ETTs compromising } \\
\text { subglottic scretions drainage }\end{array}$ & $\begin{array}{c}\text { Reduction of aspiration of bacteria-laden } \\
\text { oropharyngeal secretions across } \\
\text { ETT cuff }\end{array}$ & $\begin{array}{l}\text { Reduction in clinically/microbiologically } \\
\text { confirmed VAP } \\
\text { [risk ratio } 0.58,95 \% \mathrm{Cl} 0.51-0.67 \text { ] [17] }\end{array}$ & $\begin{array}{l}\text { No concomitant reduction in other } \\
\text { major outcomes }\end{array}$ \\
\hline $\begin{array}{l}\text { Continuous control ETT } \\
\text { cuff pressure }\end{array}$ & $\begin{array}{c}\text { Reduction of aspiration of bacteria-laden } \\
\text { oropharyngeal secretions across } \\
\text { ETT cuff }\end{array}$ & $\begin{array}{l}\text { Reduction in clinically/microbiologically } \\
\text { confirmed VAP } \\
\text { [risk ratio } 0.47,95 \% \mathrm{Cl} 0.31-0.71 \text { ] [18] }\end{array}$ & $\begin{array}{l}\text { Heterogeneous applied methods. } \\
\text { No concomitant reduction in other } \\
\text { major outcomes }\end{array}$ \\
\hline
\end{tabular}

\begin{tabular}{|c|c|c|c|}
\hline \multicolumn{4}{|c|}{ Pharmacological strategies } \\
\hline Interventions & Preventive mechanisms & Main Effect & Additional Benefits/Limitations \\
\hline Alcohol-based hand hygiene & $\begin{array}{c}\text { Broad spectrum activity against } \\
\text { pathogens present on healthcare } \\
\text { providers' hands }\end{array}$ & $\begin{array}{l}\text { Reduction of cross-contamination } \\
\text { between patients }\end{array}$ & $\begin{array}{l}\text { Achieving and maintaining optimal } \\
\text { hand hygiene practices continue } \\
\text { to be a challenge [20] }\end{array}$ \\
\hline $\begin{array}{l}\text { Oropharyngeal } \\
\text { decontamination with } \\
\text { chlorhexidine }\end{array}$ & $\begin{array}{l}\text { Broad-spectrum activity against } \\
\text { oropharyngeal pathogens }\end{array}$ & $\begin{array}{l}\text { Reduction in VAP } \\
\text { incidence up to } 40 \% \text { [20] }\end{array}$ & $\begin{array}{l}\text { Intervention mostly advantageous for } \\
\text { cardiac surgery patients. No concomitant } \\
\text { reduction in other major outcomes }\end{array}$ \\
\hline $\begin{array}{l}\text { Selective oropharyngeal } \\
\text { decontamination }\end{array}$ & $\begin{array}{l}\text { Selective eradication of aerobic } \\
\text { gram-negative bacilli, } \\
\text { methicillin-sensitive } \\
\text { Staphylococcus aureus, and yeasts }\end{array}$ & $\begin{array}{l}\text { Strong reduction in respiratory } \\
\text { infections [21] and mortality }\end{array}$ & $\begin{array}{l}\text { Effective in Dutch ICUs with low level } \\
\text { of antimicrobial resistance }\end{array}$ \\
\hline
\end{tabular}

ETT endotracheal tube, VAP ventilator-associated pneumonia, $I C U$ intensive care unit, $C l$ confidence interval

\section{Preventive bundles}

Various individual measures have proven efficacy in the prevention of VAP (Table 1), but when these measures are concomitantly applied, risks of VAP are further reduced. Meta-analyses on the implementation of VAP bundles showed that simple interventions, applied in a coordinated way as a part of a ventilator bundle care not only reduce VAP, but might also improve survival [11]. Nonetheless, as mentioned in previous paragraphs, those studies often applied inadequate methods and overlooked potential confounding factors, such as secular temporal trends in VAP incidence or regression to the mean. In addition, disagreement still exists on the most efficient and feasible bundle, since previous studies differed in the number and types of interventions, while it is known that individual components unequally impact outcomes [12].

\section{Non-pharmacological measures}

Endotracheal intubation is a main risk factor for VAP, since patients aspirate orogastric pathogens across the endotracheal tube (ETT) cuff, specifically when they are placed in the supine horizontal position. Therefore, reducing the time of intubation, through daily sedation vacation [13] and spontaneous breathing trials [14] are tenable preventive measures. Positioning the patient with the head of the bed elevated $>30^{\circ}$ reduces aspiration and clinically confirmed VAP [15], but quality of evidence supporting this intervention is poor, and the optimal 
angulation of the head of the bed is still uncertain. The Gravity-VAP trial showed that the lateral-Trendelenburg position (LTP) could further reduce VAP, specifically in patients with healthy lungs upon intubation, but LTP feasibility appeared challenging [16]. To date, only ETTs comprising aspiration of subglottic secretions [17] reduced VAP by more than $50 \%$, but substantial benefits were mostly corroborated in cardiac surgery patients. Avoiding ETT cuff deflation could further decrease pulmonary infections, as demonstrated by the use of devices that continuously control cuff pressure [18]; however, diverse machines have been used across available studies and consistent lack of benefits in secondary outcomes has been reported.

\section{Pharmacological measures}

It is firmly established that contact precautions, including hand hygiene with alcohol-based solutions, are pivotal in reducing transmission of drug-resistant pathogens [19]. These measures are endorsed by the most prominent international health agencies to reduce incidence of all nosocomial infections. Following endotracheal intubation, oropharyngeal flora shifts to a predominance of aerobic Gram-negative pathogens and Staphylococcus aureus. Thus, modulation of orogastric colonization has been a central strategy in the prevention of VAP. Various concentrations of chlorhexidine, up to $2 \%$, have been used to hinder oropharyngeal growth of pathogens [20], specifically in cardiac surgery ICU patients. Importantly, in recent years, arguments have been raised against the use of chlorhexidine, due to associated increased mortality. These findings could be anecdotal or imply extensive pulmonary aspiration of chlorhexidine, specifically in patients in the semi-recumbent position; thus, experimental/clinical corroboration is needed. Several investigators have also recommended selective digestive or oropharyngeal decontamination (SDD/SOD) to maximize eradication of gastrointestinal Gram-negative bacteria. SDD/SOD have been principally applied in Dutch ICUs, with lower prevalence of multi-drug resistant pathogens. In those settings, SDD/SOD have consistently reduced incidence of respiratory infections [21] and mortality. Potential rebound colonization and increased antibiotic resistance have been a serious concern. Indeed, even in Dutch ICUs, rising ceftazidime resistance was documented. Interestingly, a recent study [22] evaluating SDD/SOD effects on bloodstream infections was conducted in ICUs with high prevalence of antibiotic-resistance. Mortality was not affected by the interventions, while antibiotic resistance did not vary throughout the study periods.

In conclusion, although a variety of studies have demonstrated reduction in VAP, certainty of evidence in this field of investigation is still limited, due to the lack of reliable diagnostic methods, disagreement on VAP burden and substantial inconsistency, heterogeneity and risk of bias of available studies. In conclusion, we call attention to the crucial need of innovative diagnostic markers and application of improved research methods to advance this field and precisely corroborate efficacy of interventions in reducing VAP.

\begin{abstract}
Author details
${ }^{1}$ Critical Care Research Group, The Prince Charles Hospital, Brisbane, QLD, Australia. ${ }^{2}$ Department of Pathophysiology and Transplantation, Università degli Studi di Milano, Milan, Italy. ${ }^{3}$ Faculty of Medicine, University of Queensland, Brisbane, QLD, Australia. ${ }^{4}$ Department of Pneumology, Hospital Clinic of Barcelona, Barcelona, Spain. ${ }^{5}$ Universitat de Barcelona, Barcelona, Spain. ${ }^{6}$ Institut d'Investigacions, Biomèdiques August Pi i Sunyer, Barcelona, Spain.
\end{abstract}

Compliance with ethical standards

\section{Conflicts of interest}

Sebastiano Maria Colombo and Andrea Catalina Palomeque do not have conflict of interest related to this manuscript. Gianluigi Li Bassi, in the past 5 years, received grant funding, through his affiliated institution from Fisher and Paykel, Bayer AG and Theravance Biopharma.

\section{Publisher's Note}

Springer Nature remains neutral with regard to jurisdictional claims in published maps and institutional affiliations.

Received: 7 October 2019 Accepted: 26 November 2019 Published online: 16 December 2019

References

1. Torres A, Niederman MS, Chastre J et al (2017) International ERS/ESICM/ ESCMID/ALAT guidelines for the management of hospital-acquired pneumonia and ventilator-associated pneumonia: guidelines for the management of hospital-acquired pneumonia (HAP)/ventilator-associated pneumonia (VAP) of the European Respiratory Society (ERS), European Society of Intensive Care Medicine (ESICM), European Society of Clinical Microbiology and Infectious Diseases (ESCMID) and Asociación Latinoamericana del Tórax (ALAT). Eur Respir J. https://doi.org/10.1183/13993 003.00582-2017

2. Rello J, Ollendorf DA, Oster G et al (2002) Epidemiology and outcomes of ventilator-associated pneumonia in a large US database. Chest 122:2115-2121

3. Melsen WG, Rovers MM, Groenwold RH et al (2013) Attributable mortality of ventilator-associated pneumonia: a meta-analysis of individual patient data from randomised prevention studies. Lancet Infect Dis 13:665-671. https://doi.org/10.1016/S1473-3099(13)70081-1

4. Dudeck MA, Weiner LM, Allen-Bridson Ket al (2013) National Healthcare Safety Network (NHSN) report, data summary for 2012, device-associated module. Am J Infect Control 41:1148-1166. https://doi.org/10.1016/j. ajic.2013.09.002

5. Martin-Loeches I, Povoa P, Rodríguez A et al (2015) Incidence and prognosis of ventilator-associated tracheobronchitis (TAVeM): a multicentre, prospective, observational study. Lancet Respir Med 3:859-868. https:// doi.org/10.1016/S2213-2600(15)00326-4

6. Álvarez-Lerma F, Palomar-Martínez M, Sánchez-García M et al (2018) Prevention of ventilator-associated pneumonia: the multimodal approach of the Spanish ICU "Pneumonia Zero" Program. Crit Care Med 46:181-188. https://doi.org/10.1097/CCM.0000000000002736

7. Klein Klouwenberg PMC, van Mourik MSM, Ong DSY et al (2014) Electronic implementation of a novel surveillance paradigm for 
ventilator-associated events: feasibility and validation. Am J Respir Crit Care Med. https://doi.org/10.1164/rccm.201307-1376OC

8. Magill SS, Klompas M, Balk R et al (2013) Developing a new, national approach to surveillance for ventilator-associated events. Crit Care Med 41:2467-2475. https://doi.org/10.1097/CCM.0b013e3182a262db

9. Klompas M (2012) Is a ventilator-associated pneumonia rate of zero really possible? Curr Opin Infect Dis 25:176-182. https://doi.org/10.1097/ QCO.0b013e3283502437

10. Landelle C, Nocquet Boyer V, Abbas M et al (2018) Impact of a multifaceted prevention program on ventilator-associated pneumonia including selective oropharyngeal decontamination. Intensive Care Med 44:1777-1786. https://doi.org/10.1007/s00134-018-5227-4

11. Pileggi C, Mascaro V, Bianco A et al (2018) Ventilator bundle and its effects on mortality among ICU patients. Crit Care Med 46:1 167-1174. https:// doi.org/10.1097/CCM.0000000000003136

12. Klompas M, Li L, Kleinman $\mathrm{K}$ et al (2016) Associations between ventilator bundle components and outcomes. JAMA Intern Med 176:1277-1283. https://doi.org/10.1001/jamainternmed.2016.2427

13. Kress JP, Pohlman AS, O'Connor MF, Hall JB (2000) Daily interruption of sedative infusions in critically ill patients undergoing mechanical ventilation. N Engl J Med 342:1471-1477. https://doi.org/10.1056/NEJM200005 183422002

14. Girard TD, Kress JP, Fuchs BD et al (2008) Efficacy and safety of a paired sedation and ventilator weaning protocol for mechanically ventilated patients in intensive care (awakening and breathing controlled trial): a randomised controlled trial. Lancet 371:126-134. https://doi.org/10.1016/ S0140-6736(08)60105-1

15. Wang L, Li X, Yang Z et al (2016) Semi-recumbent position versus supine position for the prevention of ventilator-associated pneumonia in adults requiring mechanical ventilation. Cochrane Database Syst Rev 1:CD009946. https://doi.org/10.1002/14651858.CD009946.pub2

16. Li Bassi G, Panigada M, Ranzani OT et al (2017) Randomized, multicenter trial of lateral Trendelenburg versus semirecumbent body position for the prevention of ventilator-associated pneumonia. Intensive Care Med 43:1572-1584. https://doi.org/10.1007/s00134-017-4858-1

17. Caroff DA, Li L, Muscedere J, Klompas M (2016) Subglottic secretion drainage and objective outcomes: a systematic review and meta-analysis. Crit Care Med 44:830-840. https://doi.org/10.1097/CCM.0000000000001414

18. Nseir S, Lorente L, Ferrer M et al (2015) Continuous control of tracheal cuff pressure for VAP prevention: a collaborative meta-analysis of individual participant data. Ann Intensive Care. https://doi.org/10.1186/s1361 3-015-0087-3

19. Boyce JM (2019) Current issues in hand hygiene. Am J Infect Control 47S:A46-A52. https://doi.org/10.1016/j.ajic.2019.03.024

20. Klompas M (2017) Oropharyngeal decontamination with antiseptics to prevent ventilator-associated pneumonia: rethinking the benefits of chlorhexidine. Semin Respir Crit Care Med 38:381-390. https://doi. org/10.1055/s-0037-1602584

21. Liberati A, D'Amico R, Pifferi S et al (2009) Antibiotic prophylaxis to reduce respiratory tract infections and mortality in adults receiving intensive care. Cochrane Database Syst Rev. https://doi.org/10.1002/14651858. CD000022.pub3

22. Wittekamp BH, Plantinga NL, Cooper BS et al (2018) Decontamination strategies and bloodstream infections with antibiotic-resistant microorganisms in ventilated patients: a randomized clinical trial. JAMA 320:2087-2098. https://doi.org/10.1001/jama.2018.13765 